\title{
Molecular analysis of some endemic and near-endemic medicinal plants located at Saint Katherine, Egypt
}

\author{
Samy Afiah ${ }^{1}$, Ibtisam Hammad ${ }^{2}$, Lamiaa Zedan ${ }^{2}$ \\ ${ }^{I}$ Department of Genetic Resources, Desert Research Center, El-Matareya, Cairo, Egypt \\ ${ }^{2}$ Department of Botany, Faculty of Science, Helwan University, Cairo, Egypt
}

\begin{abstract}
The present study focused on genetically studies of endemic and near endemic medicinal plants from Saint Katherine Protectorate, Egypt, using ISSR and RAPD markers. The three plants Nepeta septemcrenat "near-endemic", thymus decussates "near-endemic" and Phlomis aurea "endemic" were collected from Wadi Elfaraa, Saint Katherine, Egypt. For RAPD-PCR analysis five primers has been evaluated. A total of 35 DNA bands were detected, 17 bands were polymorphic, 18 were monomorphic. The percentage of polymorphic bands ranged from $25 \%$ to $72.72 \%$ with an average of $44.18 \%$. The amplified DNA bands ranges in size between 89 to $1457 \mathrm{bp}$. For ISSR analysis, DNAs of the three selected plants were subjected to PCR against 7 ISSR Primers. A total of 46 DNA bands were detected, 23 bands were polymorphic, 23 were monomorphic. The percentage of polymorphic bands ranged from $16.667 \%$ to $77.778 \%$ with an average of $47.89 \%$. The amplified DNA bands ranges in size between 112 to 7403 bp Genetic distance between populations for RAPD-PCR ranged from 0.66 to 0.71 while ISSR-PCR ranged from 0.61 to 0.78 . The efficiency of the discriminatory power "Dj" is an extension of the PIC and provides an estimate of the probability that two randomly chosen individuals show different banding patterns for the same primer and, thus, are distinguishable from one another. Discriminatory power is a direct indication of primer efficiency. The Dj values for RAPD-PCR markers tested ranged from 0.73 to 0.87 and for ISSR-PCR markers tested ranged from 0.78 to 0.86 .
\end{abstract}

Keywords: discriminatory power, endemic and near-endemic plants, medicinal plants, molecular markers, Saint Katherine.

\section{Introduction}

With its high mountains and deep wadies in the southern Sinai Peninsula and its relatively unexplored desert ecosystem of wild plants, Saint Katherine Protectorate (SKP) is as one of region's most amazing areas not only for its natural landscapes, but also for its medicinal plant diversity that has national and global interest.

The SKP contains a wide range of habitats and landscapes that are a consequence of varying climatic conditions, a wide range of altitudes, and variable topography [1]. SKP is one of the most floristically diverse spots in the Middle East and with 44\% of Egypt's endemic plant species. 1261 species were recorded in Sinai [2]. 472 plant species have been recorded as surviving and still occurring in south Sinai [3] of these 19 species are endemic [2] and about 170 are with known by medicinal properties used in traditional therapy and remedies. It is currently recognized as one of the central regions for flora diversity in the Middle East by the World Conservation Union, WWF \& IUCN 1994 [4].

In the past few years, the Sinai peninsula has attracted a great deal of scientific attention both as a new axis of development of Egypt and as an important phytogeographic province. The recent socioeconomic and the tourist industry development of Sinai are based on previous evaluation of its natural resources soil, water, animal and plant wild-life. Proper knowledge of these resources will help plan for the future development and conservation of its natural treasures. Studies dealing with the evaluation of these natural resources and monitoring of the changes taking place are needed, especially ecological studies [5]. The preservation of genetic diversity is important, because it provides long-term evolutionary potential for changing environmental conditions [6].

Medicinal plants have a very important role from the medical and economical point of view all over the world, where the folk medicine made a wide base used for searching new drug. Family Lamiaceae comprises many species of special economic and medicinal importance due to their different constituents [7].It is represented in Egypt by 21 genera [8] among them Thymus, Nepeta and Phlomis. Some species of Nepeta genus are important medicinal plants and their extracts have been used for medicinal purposes [9], Nepeta septemcrenata known to be used by the native Bedouins in folk medicine as antipyretic, sedative, cardiotonic, eye wash and as a gargle in sore throat[10]. Phlomis genus has been instrumental in the discovery of natural medicinal products [11]. Phlomis species are used to treat various conditions such as diabetes, gastric ulcer, hemorrhoids, inflammation, and wounds, Phlomis aurea is recognized for its antidiabetic properties due to its ability to protect liver and pancreas integrity by reducing the oxidative stress in diabetes or by stimulating the production of enzymes implicated in glucose metabolism [12]. Thymus species are well known as medicinal 
Molecular analysis of some endemic and near-endemic medicinal plants located at Saint Katherine,

plants because of their biological and pharmacological properties. In traditionalmedicine, leaves and flowering parts of Thymus species are widely used as tonic and herbal tea, antiseptic, antitussive, and carminative as well as treating colds $[13,14]$.In recent years, molecular markers derived from DNA using electrophortic techniques have provided powerful markers for the study of several aspects in all biological fields including systematic and genetic relationships of plant species and sub-specific ranks.Currently techniques of choice is the RAPD-PCR and ISSR-PCR. RAPD-PCR is based on using the PCR as proposed by [15] to amplify DNA sequences with single short $9-10 \mathrm{bp}$ primers of arbitrary nucleotide sequence. It requires small

amounts of DNA, easy to perform and reveals dominant molecular markers of ultimate potentialities in several fields of plant science including systematic and evolution [16]. Many authors have utilized the RAPD-PCR approach to study genetic diversity and species relationships in some plant genera. The applications of RAPD in plant biodiversity also included investigation of genetic diversity some species of lamiacea were used; Nepeta septemcrenata species [17], Cunila Incisa Benth [18], Salvia [19], Thymus [20] and Thymes [21].

ISSR marker is involving PCR amplification of DNA by a single 16-18 bp long primer composed of a repeated sequence anchored at the 3 ' or 5' end of 2-4 arbitrary nucleotides [22]. The technique is rapid, simple, inexpensive and more reproducible than RAPD [23]. ISSR used to study the genetic diversity of plants for examples; Nepeta [24], thyme [25], Mentha aquatica L. [26], satureja [27], Salvia [28], Dracocephalum thymiflorum L. [29] and Thymus [30]. RAPD and ISSR markers have been extensively used for genetic diversity for example: the investigation for some species of lamiaceae by RAPD and ISSR; Salvia [19] , Phlomis kurdica and Phlomis oppositiflora [31], Ocimum [32] and Morus [33]. The goal of this research was to study the molecular fingerprint for the three endemic and near-endemic plants by using RAPD and ISSR techniques.

\subsection{Plant materials:}

\section{Materials And Methods}

Fresh leaves of Nepeta septemcrenata, thymus decussates and Phlomis aurea were collected from Wadi Elfaraa in Saint Katherine Protectorate during the Spring season May, 2013.Scientific names, Families and Geographic location " Trimble model" shown in Table 1.

\subsection{Genomic DNA isolation:}

Young fresh leaves of each studied plant were collected and then samples of one gram was treated with liquid nitrogen and transferred to the laboratory of biotechnology in Desert Research Center (DRC), Cairo, Egypt for DNA extraction according to the method of Welsh and McCleland [34].

\subsection{Random amplified polymorphism DNA (RAPD)technique:}

Asset of 5-base oligonucleotide primers A1, A4, A9, B8, and B9 according to [15] as shown in Table 2.a. Agarose gel of $1.5 \%$ containing ethidium bromide $0.5 \mu \mathrm{g} / \mathrm{ml}$ in $1 \mathrm{X}$ TBE buffer at 95 volts was used for resolving the PCR products. Ladder Promaga lnc. of DNA was used as a DNA standard size marker "in bp" of the resulted 13 bands 10000, 8000, 6000, 5000, 4000, 3500, 2500, 2000, 1500, 1000, 750, 500 and 250 bp. PCR products were visualized on UV light and photographed using a gel documentation system "Bio-Rad® Gel Doc2000". Gels were analyzed by gel documentation system.

Amplified products were visually examined and the presence or absence of each size class was scored as 1 or 0 ; respectively as shown in table 3.a.

\subsection{Inter Simple Sequence Repeat (ISSR-PCR) technique:}

Inter-Simple Sequence Repeats "ISSRs" has only recently been developed as an anonymous, RAPDslike approach that accesses variation in the numerous microsatellite regions dispersed throughout the various genomes "particularly the nuclear genome" and circumvents the challenge of characterizing individual loci that other molecular approaches require. Microsatellites are very short usually 10-20 base-pair stretches of DNA that are "hyper variable", expressed as different variants within populations and among different species [35]. DNA isolation of plant samples for each studied species was conducted according to the method outlined by [36]. ISSR - PCR reactions were conducted using 7 selective primers A11. A12, A15, 17898A, 17898B, 17899A and 17899B table 2.b.

\subsection{Statistical analysis:}

RAPD-PCR and ISSR-PCR amplified fragments were scored as present 1 or absent 0 . Only clear and major bands were scored according to [37] Table 3.a,b. RAPD and ISSR analyses were performed by the Nei genetic similarity index [38] on the basis of the equation: $\mathrm{SI}=2 \mathrm{Nij} /(\mathrm{Ni}+\mathrm{Nj})$, where $\mathrm{Nij}$ is the number of common bands shared between samples $\mathrm{i}$ and $\mathrm{j}, \mathrm{Ni}$ and $\mathrm{Nj}$ are the total number of DNA bands for genotypes $\mathrm{i}$ and j, respectively. A dendrogram was constructed Figure 3.a,b,c. Dendrogram using the neighbor joining method of cluster analysis. 
Molecular analysis of some endemic and near-endemic medicinal plants located at Saint Katherine,

The discriminatory power $(\mathrm{Dj}=1-\mathrm{Cj})$ and confusion probability $(\mathrm{Cj})$ of the $\mathrm{j}^{\text {th }}$ assay [39] were calculated according to the following equation: $\mathrm{Cj}=\sum \mathrm{Ii}=1 \mathrm{pi}(\mathrm{Npi}-1) / \mathrm{N}-1$ Where, pi represents the frequency of the $\mathrm{i}^{\text {th }}$ pattern, $\mathrm{N}$ the sample size, and $\mathrm{I}$ is the total number of pattern.

\subsection{RAPD analysis}

\section{Results}

Five RAPD primers were used to differentiate between the three plants. The size of the amplified fragments ranged from 89 to 1457 bp generated 35 DNA bands, 17 bands were polymorphic, and 18 were monomorphic. The number of bands varied from 4 (primer OPA- 09 \& OPB-08) to 11 (primer OPA-01) with an average of 17.5 markers per primer Table 4.a. and figure 1. The polymorphism level ranged from $25 \%$ to $72.72 \%$ with an average of $44.18 \%$.Minimum and maximum number of polymorphic bands were obtained with the primer B8 1 and A1 8, respectively Table 4.a. Cluster analysis based on the similarity index of [40] revealed two main clusters Fig. 3.a One of them separate S.1 Nepeta septemcrenata as a genetically dissimilar genotype with all other one's. While the second cluster was separated into two sub-clusters comprised the first involved S.2 Phlomis aurae and the second sub-cluster S.3 Thymus decussatus; this indicates that Thymus decussates and Phlomis aurea are genetically close to each other than Nepeta septemcrenata. as illustrated in table (5.a) similarity indices ranged from 0.74 between Nepeta septemcrenata and Phlomis aurae, to 0.81 between Phlomis aurae and Thymus decussates.

The discriminatory power "Dj" Table 6 which indicate primer efficiency for RAPD ranged from0.734 to 0.865 .

\subsection{ISSR analysis}

Seven ISSR primers were used.Fig 2 and table 4.b. The size of the amplified fragmentss ranged from 112- 7403 bp. 7 ISSR primers generated 46 bands, which 23 bands polymorphicand 23 were monomorphic. The number of bands varied from 5 "primer 17898B" to 9 "primer 17898A" with an average of 6.57 markers per primer. The polymorphism level, calculated as the number of polymorphic bands per primer ranged from $16.667 \%$ to $77.778 \%$ Minimum and maximum number of polymorphic bands were obtained with the primer HB12 "1" and 17898A "7", respectively Table 3. Cluster analysis revealed two main clusters one of them separate S.1 Nepeta septemcrenata as a genetically dissimilar genotype with all other one's. While the second cluster was separated into two sub-clusters comprised the first involved S.2 Phlomis aurae and the second subcluster S.3 Thymus decussatus; this indicates that Thymus decussates and Phlomis aurea are genetically close to each other than Nepeta septemcrenata Fig. 3.b. Similarity indices ranged from 0.73 between Nepeta septemcrenata and Thymus decussates to 0.86 between Phlomis aurae and Thymus decussates. Table 5.b.

The discriminatory power "Dj" for ISSR ranged from 0.777 To 0.859 .

\subsection{Combined RAPD and ISSR analysis}

The RAPD and ISSR data were combined for similarity and cluster analyses. Fig. Cluster analysis performed on combining data of both markers revealed two main clusters.one of them separate S.1 Nepeta septemcrenata as a genetically dissimilar genotype with all other one's. While the second cluster was separated into two sub-clusters comprised the first involved S.2 Phlomis aurae and the second sub-cluster S.3 Thymus decussatus; this indicates that Thymus decussates and Phlomis aurea are genetically close to each other than Nepeta septemcrenata. Fig 3.c. Similarity indices ranged between 0.74 to 0.83 . Similarity indices show that the highest similarity value 0.83 was recorded between Phlomis aurea and Thymus decussates, indicating that these two plants were closely related to each other than Nepeta septemcrenata which show the lowest similarity value with Phlomis aurae 0.74 and Thymus decussates 0.76 .Table 5.c. The discriminatory power "Dj" for RAPDPCR markers tested ranged from 0.734 to 0.865 , with average 0.806 . and for ISSR-PCR markers tested ranged from an estimate of the probability that two randomly chosen individuals 0.777 To 0.859 , with average 0.811 . table 6.

\section{Discussion}

In the present study, RAPD and ISSR markers were applied to assess the genetic diversity between three plants (Nepeta septemcrenata, Phlomis aurea, Thymus decussates). The ISSR primers generated more polymorphic bands 23 than RAPD primers 17, so ISSRs were found to be more efficient over RAPDs in estimating genetic diversity. Similar results have been obtained for several other plants including Salvia [19] , Phlomis [31]. Morus alba [33], Ocimum [32]. Dendrogram constructed using the neighbor joining method of cluster analysis revealed two main clusters for RAPD and ISSR. Cluster analysis was also carried out on two sets of marker profiling data based on RAPD and ISSR combination which grouped the three plants into two main clusters. First cluster included Nepeta septemcrenata in all of three studied marker systems.and the second cluster was separated into two sub-clusters, one of them involved Phlomis aurea and the other involved Thymus decussates. we expected high genetic distance between Nepeta septemcrenata and the two other plants Phlomis 
Molecular analysis of some endemic and near-endemic medicinal plants located at Saint Katherine,

aurea and Thymus decussates which more closely related. Variations in DNA sequences lead to polymorphism and greater polymorphism are indicative of greater genetic diversity. According to similarity indices The high similarity between Phlomis aurea and Thymus decussatus was obtained in RAPD 0.81,ISSR 0.83 and RAPD+ISSR Combined 0.83 .These results indicate that these two species are closely related. This result in harmony with [19] and [31] Primer efficiency is an important parameter, especially in cases where random primers are used for genetic diversity analysis.discriminatory power " $\mathrm{Dj}$ ", introduced by [39] is the most effective method to know the primer ability in distinguishing the cropplant genotypes using random markers. The $D j$ values for both RAPD and ISSR markers ranged from0.734 to 0.865 RAPD with average 0.80 and 0.777 To 0.859 ISSR with average 0.81 respectively. The efficiency of the $D j$ is an extension of the PIC and provides an estimate of the probability that two randomly chosen individuals show different banding patterns for the same primer and, thus, are distinguishable from one another. Discriminatory power, a direct indication of primer efficiency, prevents the use of those primers which show less efficiency in distinguishing the genotypes. In the current study Dj values Dj values lower for RAPDs than for ISSRs. [41] revealed similar results.

\section{Conclosion}

The three plants under study Nepeta septemcrenata, Phlomis aurea and Thymus decussates are very rare, endangered and severely threatened by both natural and human factors. Also characterized by high medical value so study genetic fingerprint help in plants preservation and benefits. RAPD and ISSR markers were applied to assess the genetic diversity between three plants. The two sets of marker profiling data based on RAPD and ISSR combination which grouped the three plants into two main clusters. First cluster included Nepeta septemcrenata in all of three studied marker systems. and the second cluster was separated into two subclusters, one of them involved Phlomis aurea and the other involved Thymus decussates. we expected high genetic distance between Nepeta septemcrenata and the two other plants Phlomis aurea and Thymus decussates which more closely related.

VI. Figures And Tables

Table 1: scientific names, family, location and vernacular names of the studied plant

\begin{tabular}{|c|c|c|}
\hline $\begin{array}{l}\text { Scientific } \\
\text { names/Family }\end{array}$ & Location/GPS & Vernacular names \\
\hline $\begin{array}{l}\text { Nepeta } \\
\text { septemcrenatat } \\
\text { (Lamiaceae) }\end{array}$ & $\begin{array}{l}\text { Wadi Elfaraa: North: } 28.539368 \text { East: } \\
\text { 33.967015 Altitude: } 1873\end{array}$ & (زيثبه) Zayteya \\
\hline $\begin{array}{l}\text { Phlomis aurea } \\
\text { Lamiaceae }\end{array}$ & $\begin{array}{l}\text { Wadi Elfaraa: } \\
\text { North: } 28.539368 \text { East: } 33.967015 \\
\text { Altitude: } 1873\end{array}$ & $\begin{array}{l}\text { Awarwar } \\
(\text { (عور.ور) }\end{array}$ \\
\hline $\begin{array}{l}\text { Thymus decussates } \\
\text { (Lamiaceae) }\end{array}$ & $\begin{array}{l}\text { Wadi Elfaraa: North: } 28.539368 \text { East: } \\
33.967015 \text { Altitude: } 1873\end{array}$ & Zyteran \\
\hline
\end{tabular}

Table 2.a: List of RAPD Operon primers and their nucleotide sequences

\begin{tabular}{|l|l|l|l|}
\hline Primer Code & Primer Sequences & Primer Code & Primer Sequences \\
\hline A1 & 5CAGGTTTTTC3 & B 8 & 5TGCTCTCTGCC3 \\
\hline A4 & 5AAGTTTGCTC3 & B 9 & 5GGTGACGCAG3 \\
\hline A9 & 5GGGTAACGCC3 & & \\
\hline
\end{tabular}

Table 2.b: List of ISSR Operon Primers and their nucleotide sequences

\begin{tabular}{|l|l|l|l|}
\hline Primer Code & Primer Sequences & Primer Code & Primer Sequences \\
\hline HB11 & (GT)6CC & $17898 \mathrm{~B}$ & (CA)6 GT \\
\hline HB12 & (CAC)3GC & $17899 \mathrm{~A}$ & $\mathbf{( C A ) 6 ~ A G ~}$ \\
\hline HB15 & (GTC)3GC & $17899 \mathrm{~B}$ & (CA)6 GG \\
\hline 17898A & (CA)6 AC & & \\
\hline
\end{tabular}

Table 3.a: RAPD polymorphism in three plants genotypes tested using RAPD-PCR with five primers

\begin{tabular}{|l|l|l|l|l|l|l|}
\hline Primer & Amplicon & BP & 1 & 2 & 3 & $\mathrm{M}$ \\
\hline A1 & AF1 & 1457 & 1 & 1 & 1 & \\
\cline { 2 - 7 } & AF2 & 719 & 1 & 0 & 0 & $\mathrm{M}^{+}$ \\
\cline { 2 - 7 } & AF3 & 679 & 0 & 1 & 1 & $\mathrm{M}^{-}$ \\
\cline { 2 - 7 } & AF4 & 588 & 1 & 0 & 0 & $\mathrm{M}^{+}$ \\
\cline { 2 - 7 } & AF5 & 521 & 0 & 1 & 0 & $\mathrm{M}^{+}$ \\
\cline { 2 - 7 } & AF6 & 418 & 0 & 0 & 1 & $\mathrm{M}^{+}$ \\
\cline { 2 - 7 } & AF7 & 294 & 1 & 1 & 1 & \\
\cline { 2 - 7 } & AF8 & 206 & 0 & 1 & 0 & $\mathrm{M}^{+}$ \\
\hline
\end{tabular}


Molecular analysis of some endemic and near-endemic medicinal plants located at Saint Katherine,

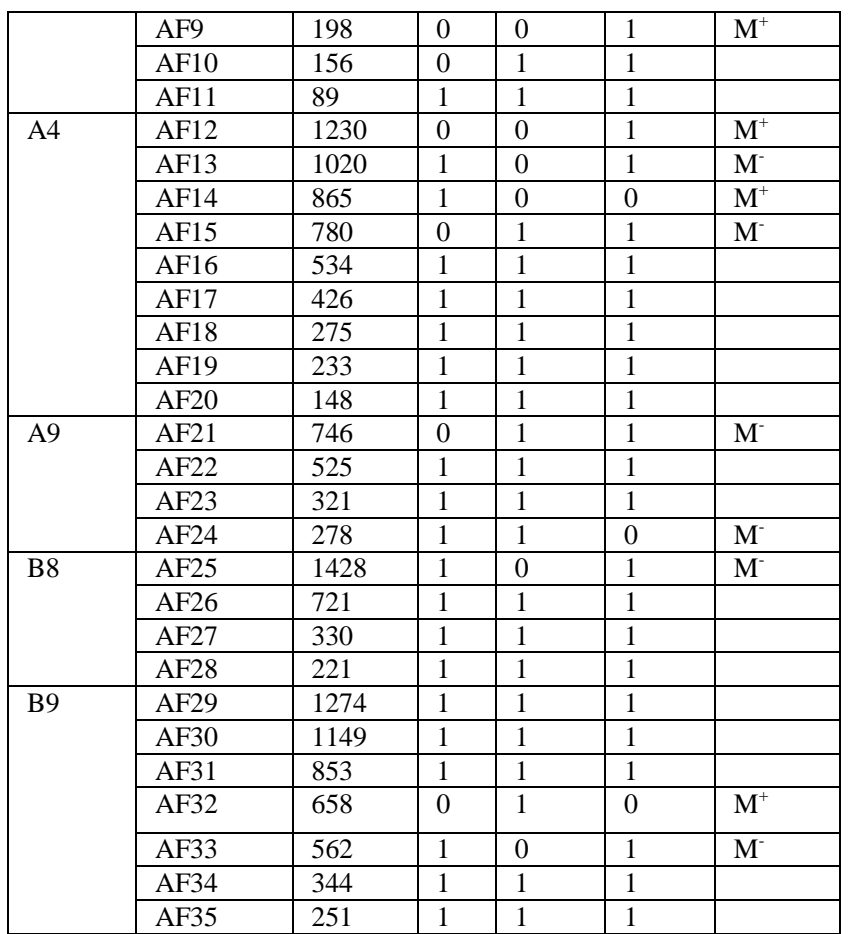

Table 3.b: ISSR polymorphism in the three plants tested using ISSR-PCR with seven primers

\begin{tabular}{|c|c|c|c|c|c|c|}
\hline primer & Amplicon & $\mathrm{BP}$ & 1 & 2 & 3 & $\mathbf{M}$ \\
\hline \multirow[t]{6}{*}{ HB11 } & AF01 & 692 & 1 & 1 & 1 & \\
\hline & AF02 & 557 & 0 & 1 & 1 & $\mathrm{M}^{-}$ \\
\hline & AF03 & 491 & 1 & 0 & 0 & $\mathrm{M}^{+}$ \\
\hline & AF04 & 223 & 1 & 0 & 0 & $\mathrm{M}^{+}$ \\
\hline & AF05 & 147 & 1 & 0 & 1 & $\mathrm{M}^{-}$ \\
\hline & AF06 & 112 & 1 & 1 & 1 & \\
\hline \multirow[t]{6}{*}{ HB12 } & AF07 & 6035 & 0 & 1 & 1 & $\mathrm{M}^{-}$ \\
\hline & AF08 & 1030 & 1 & 1 & 1 & \\
\hline & AF09 & 604 & 1 & 1 & 1 & \\
\hline & AF10 & 442 & 1 & 1 & 1 & \\
\hline & AF11 & 329 & 1 & 1 & 1 & \\
\hline & AF12 & 230 & 1 & 1 & 1 & \\
\hline \multirow[t]{8}{*}{ HB15 } & AF13 & 7403 & 0 & 1 & 1 & $\mathrm{M}^{-}$ \\
\hline & AF14 & 2182 & 1 & 1 & 1 & \\
\hline & AF15 & 1356 & 0 & 1 & 1 & \\
\hline & AF16 & 775 & 1 & 1 & 1 & \\
\hline & AF17 & 569 & 1 & 1 & 1 & \\
\hline & AF18 & 368 & 1 & 1 & 1 & \\
\hline & AF19 & 263 & 1 & 1 & 1 & \\
\hline & AF20 & 141 & 1 & 0 & 0 & \\
\hline \multirow[t]{9}{*}{ 17898A } & AF21 & 4742 & 0 & 1 & 0 & $\mathrm{M}^{+}$ \\
\hline & AF22 & 4626 & 1 & 0 & 0 & $\mathrm{M}^{+}$ \\
\hline & AF23 & 2240 & 0 & 1 & 0 & $\mathrm{M}^{+}$ \\
\hline & AF24 & 2041 & 1 & 0 & 1 & \\
\hline & AF25 & 1298 & 1 & 1 & 1 & \\
\hline & AF26 & 841 & 1 & 1 & 0 & \\
\hline & AF27 & 652 & 1 & 1 & 1 & \\
\hline & AF28 & 344 & 1 & 1 & 0 & \\
\hline & AF29 & 287 & 0 & 0 & 1 & \\
\hline \multirow[t]{5}{*}{ 17898B } & AF30 & 1261 & 1 & 1 & 1 & \\
\hline & AF31 & 1003 & 0 & 0 & 1 & $\mathrm{M}^{+}$ \\
\hline & AF32 & 827 & 1 & 1 & 1 & \\
\hline & AF33 & 646 & 1 & 1 & 1 & \\
\hline & AF34 & 466 & 1 & 1 & 1 & \\
\hline \multirow[t]{6}{*}{ 17899A } & AF35 & 1728 & 0 & 1 & 0 & $\mathrm{M}^{+}$ \\
\hline & AF36 & 1333 & 1 & 1 & 1 & \\
\hline & AF37 & 749 & 0 & 1 & 1 & $\mathrm{M}^{-}$ \\
\hline & AF38 & 622 & 1 & 1 & 0 & $\mathrm{M}^{-}$ \\
\hline & AF39 & 445 & 1 & 1 & 1 & \\
\hline & AF40 & 260 & 0 & 1 & 1 & $\mathrm{M}^{-}$ \\
\hline
\end{tabular}


Molecular analysis of some endemic and near-endemic medicinal plants located at Saint Katherine,

\begin{tabular}{|l|l|l|l|l|l|l|}
\hline 17899B & AF41 & 851 & 0 & 1 & 1 & $\mathbf{M}^{-}$ \\
\cline { 2 - 7 } & AF42 & 689 & 1 & 1 & 1 & \\
\cline { 2 - 7 } & AF43 & 400 & 1 & 1 & 1 & \\
\cline { 2 - 7 } & AF44 & 511 & 1 & 0 & 0 & $\mathbf{M}^{+}$ \\
\cline { 2 - 7 } & AF45 & 288 & 1 & 1 & 1 & \\
\cline { 2 - 7 } & AF46 & 191 & 0 & 1 & 1 & M $^{-}$ \\
\hline
\end{tabular}

Table 4.a: Amplification results of the five RAPD primers for the three plants tested

\begin{tabular}{|c|c|c|c|c|c|c|c|c|c|c|}
\hline \multirow[t]{3}{*}{ Primers } & \multirow[t]{3}{*}{ TAF } & \multirow[t]{3}{*}{$\mathbf{P B}$} & \multirow[t]{3}{*}{$\mathbf{P \%}$} & \multicolumn{6}{|c|}{ Genotypes } & \multirow[t]{3}{*}{ TSM } \\
\hline & & & & \multicolumn{2}{|c|}{ G1 } & \multicolumn{2}{|l|}{ G2 } & \multicolumn{2}{|l|}{ G3 } & \\
\hline & & & & $\mathrm{AF}$ & SM & $\mathrm{AF}$ & SM & $\mathrm{AF}$ & SM & \\
\hline A1 & 11 & 8 & $72.72 \%$ & 5 & 3 & 7 & 4 & 7 & 1 & \\
\hline A4 & 9 & 4 & $44.444 \%$ & 7 & 2 & 6 & 1 & 8 & 1 & \\
\hline A9 & 4 & 2 & $50 \%$ & 3 & 1 & 4 & 0 & 3 & 1 & \\
\hline B8 & 4 & 1 & $25 \%$ & 4 & 0 & 3 & 1 & 4 & 0 & \\
\hline B9 & 7 & 2 & $28.71 \%$ & 6 & 0 & 6 & 2 & 6 & 0 & \\
\hline
\end{tabular}

$\mathrm{TAF}=$ total number of amplified fragments, $\mathrm{PB}=$ polymorphic bands, $\mathrm{P} \%=$ polymorphism percentage, $\mathrm{AF}=$ amplified fragment, $\mathrm{SM}=$ genotype specific marker including either the presence or absence of agiven band, $\mathrm{TSM}+$ total number of specific markers.

Table 4.b: Amplification results of the seven ISSR primers for the three plants tested

\begin{tabular}{|c|c|c|c|c|c|c|c|c|c|c|}
\hline \multirow[t]{3}{*}{ primers } & \multirow[t]{3}{*}{ TAF } & \multirow[t]{3}{*}{ PB } & \multirow[t]{3}{*}{$\mathbf{P} \%$} & \multicolumn{6}{|c|}{ Genotypes } & \multirow[t]{3}{*}{ TSM } \\
\hline & & & & \multicolumn{2}{|c|}{ G1 } & \multicolumn{2}{|l|}{ G2 } & \multicolumn{2}{|l|}{ G3 } & \\
\hline & & & & $\mathrm{AF}$ & $\mathrm{SM}$ & $\mathrm{AF}$ & SM & $\mathrm{AF}$ & SM & \\
\hline HB11 & 6 & 4 & $66.667 \%$ & 5 & 3 & 3 & 1 & 4 & 0 & 4 \\
\hline HB12 & 6 & 1 & $16.667 \%$ & 5 & 1 & 6 & 0 & 6 & 0 & 1 \\
\hline HB15 & 8 & 3 & $37.5 \%$ & 6 & 3 & 7 & 0 & 7 & 0 & 3 \\
\hline $17898 \mathrm{~A}$ & 9 & 7 & $77.778 \%$ & 6 & 1 & 7 & 2 & 7 & 5 & 8 \\
\hline 17898B & 5 & 1 & $20 \%$ & 4 & 0 & 4 & 0 & 5 & 1 & 1 \\
\hline $17899 \mathrm{~A}$ & 6 & 4 & $66.667 \%$ & 3 & 2 & 5 & 1 & 4 & 2 & 5 \\
\hline 17899B & 6 & 3 & $50 \%$ & 4 & 3 & 5 & 0 & 5 & 0 & 3 \\
\hline
\end{tabular}

$\mathrm{TAF}=$ total number of amplified fragments, $\mathrm{PB}=$ polymorphic bands, $\mathrm{P} \%=$ polymorphism percentage, $\mathrm{AF}=$ amplified fragment, $\mathrm{SM}=$ genotype specific marker including either the presence or absence of agiven band, $\mathrm{TSM}+$ total number of specific markers.

Table 5. a- Similarity indices obtained for RAPD

\begin{tabular}{|l|l|l|l|}
\hline & Nepeta septemcrenata & Phlomis aurea & Thymus decussatus \\
\hline Nepeta septemcrenata & 1.00 & & \\
\hline Phlomis aurea & 0.74 & 1.00 & \\
\hline Thymus decussatus & 0.79 & 0.81 & 1.00 \\
\hline
\end{tabular}

Table 5.b- Similarity indices obtained for ISSR

\begin{tabular}{|l|l|l|l|}
\hline & Nepeta septemcrenata & Phlomis aurea & Thymus decussatus \\
\hline Nepeta septemcrenata & 1.00 & & \\
\hline Phlomis aurea & 0.74 & 1.00 & \\
\hline Thymus decussatus & 0.73 & 0.86 & 1.00 \\
\hline
\end{tabular}

Table 5.C- Similarity indices obtained for RAPD and ISSR

\begin{tabular}{|l|l|l|l|}
\hline & Nepeta septemcrenata & Phlomis aurea & Thymus decussatus \\
\hline Nepeta septemcrenata & 1.00 & & \\
\hline Phlomis aurea & 0.74 & 1.00 & \\
\hline Thymus decussatus & 0.83 & 0.76 & 1.00 \\
\hline
\end{tabular}

Table 6. Levels of genetic information (Discriminating power, Dj) generated by 5 RAPD-PCR primers and 7 ISSR-PCR Primers on the three endemic and near endemic plants tested.

\begin{tabular}{|c|c|c|c|}
\hline RAPD Primer & $\mathrm{Dj}$ & ISSR Primer & $\mathrm{Dj}$ \\
\hline A1 & 0.855 & HB11 & 0.777 \\
\hline $\mathbf{A 4}$ & 0.865 & HB12 & 0.829 \\
\hline A9 & 0.734 & HB15 & 0.859 \\
\hline B8 & 0.741 & 17898A & 0.84 \\
\hline \multirow[t]{3}{*}{ B9 } & 0.839 & 17898B & 0.77 \\
\hline & & 17899A & 0.803 \\
\hline & & 17899B & 0.804 \\
\hline average $\mathrm{Dj}$ & 0.8068 & & 0.8117 \\
\hline
\end{tabular}




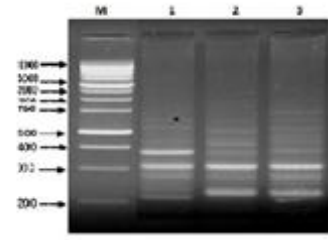

Operon Primer A4

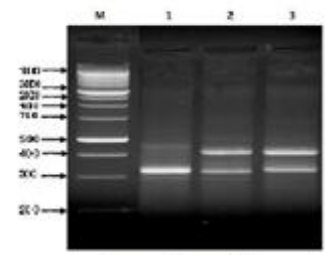

Operon Primer A9

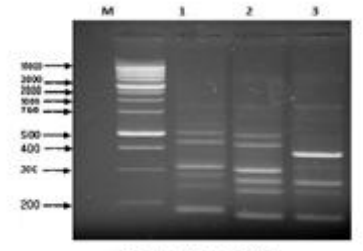

Operon Primer A1

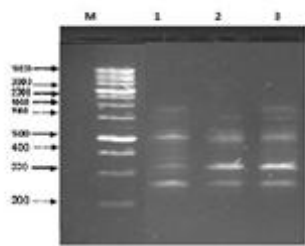

Operon Primer B8

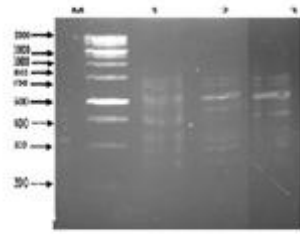

OperonPrimer B9

Figure 1. Polymorphic bands generated by different RAPD Primers

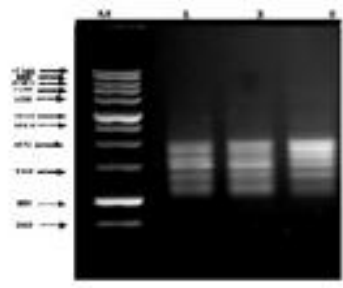

Primer 178988

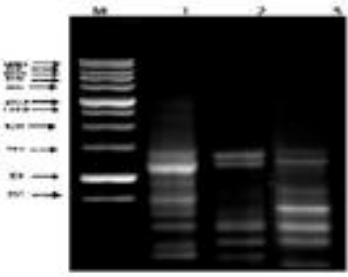

Primer HB11

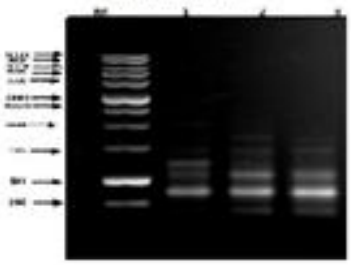

Primer 178998

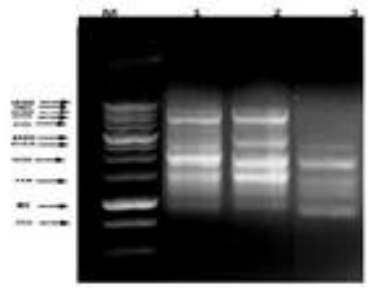

Primer 17898A

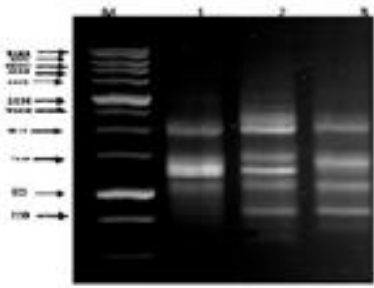

Primer $17899 \mathrm{~A}$

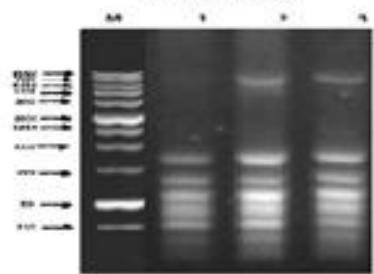

Primer HB 12

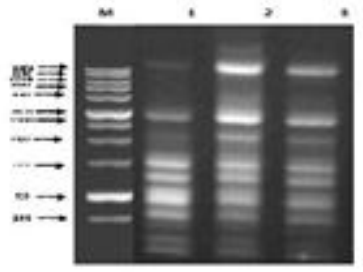

Primer HB 15

Fizure 2. Polymorphic basds generated by different ISSR peimers 

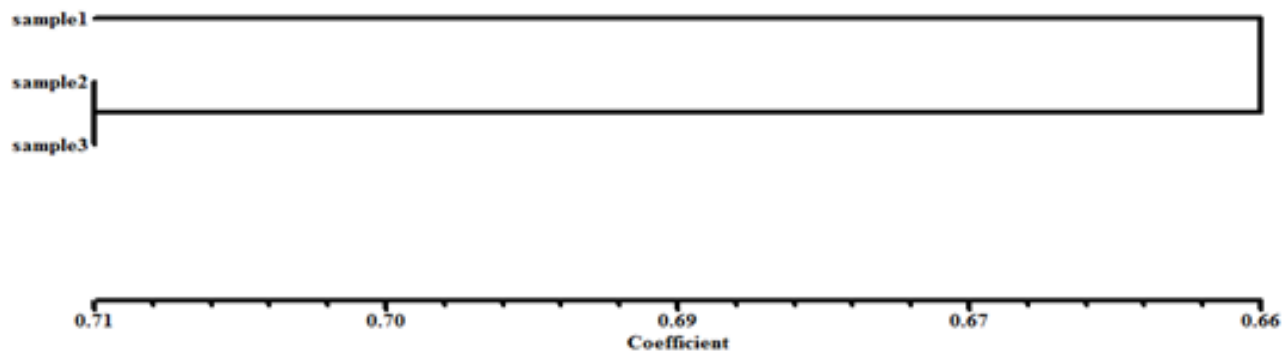

Fig. 3.a: Dendrogram constructed according to UPGMA cluster analysis, based on the similarity index of Nei (1978), showing the genetic relationships between three plants based on RAPD Primers analysis.
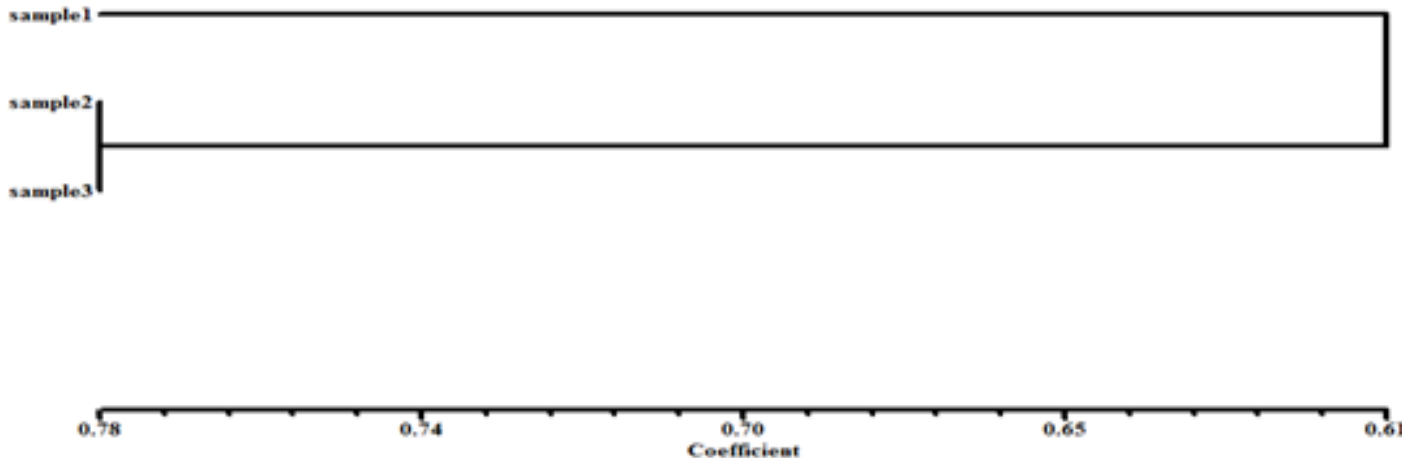

Fig. 3.b: Dendrogram constructed according to UPGMA cluster analysis, based on the similarity index of Nei (1978), showing the genetic relationships between three plants based on ISSR Primers analysis.
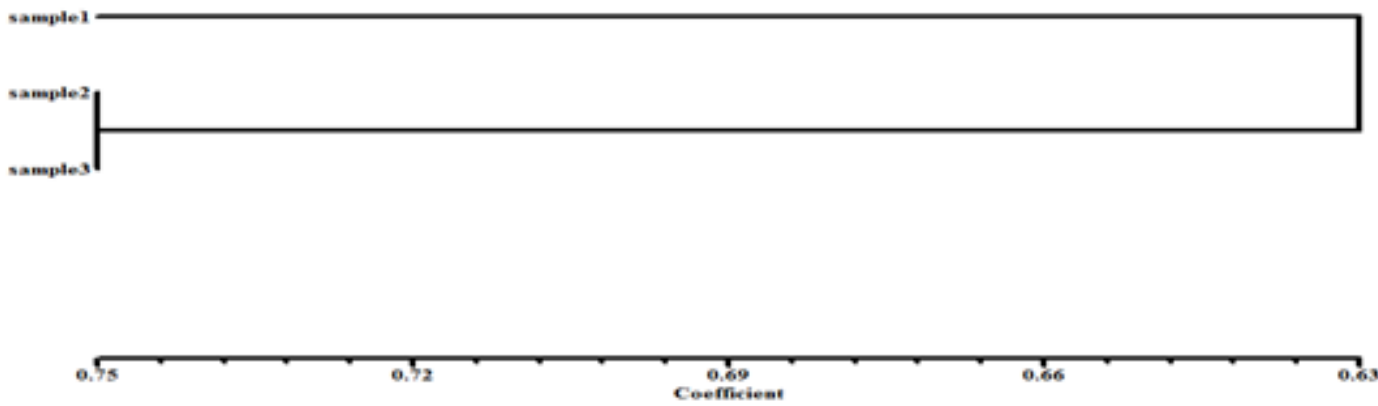

Fig.3.c: Dendrogram constructed according to UPGMA cluster analysis, based on the similarity index of Nei (1978), showing the genetic relationships between three plants based on RAPD and ISSR Primers analysis.

\section{References}

[1]. H E. El-Alqmay, T. Khafaga, E E. Hatab, Assessment of the impact of Paris-Dakar-Sharm El-Sheikh Rally on the Floral Diversity in Saint Katherine Protectorate, South Sinai, Egypt. Al-Azhar Bull. Sci. 15(2), 2004, 43-60.

[2]. L. Boulos, Flora of Egypt, Checklist (Al hadara publishing, Cairo,Egypt, 1995)

[3]. Fayed and Shaltout. Conservation and sustainable use of Medicinal plants in arid and semi-arid eco-systems project, Egypt (GEF, UNDP) (project no: 12347/12348), Flora of Saint Catherine protectorate, final report. And Floristic Survey of the Mountainous Southern Sinai: Saint Katherine Protectorate, final report, 2004.

[4]. Davis SD, Heywood VH and Hamilton AC. Centres of plant Diversity. A Guide and Strategy for their Conservation. Volume 1. Europe, Africa, South West Asia and the Middle East (WWF \& IUCN, IUCN Publication Unit, Cambridge, 1994).

[5]. A. El-Gazzar, MA. El-Demerdash, HF. El-Kady and S. Henidey, Plant life in the Gulf of Aqaba area (S. Sinai, Egypt). Final report submitted to the department of protectorates of the Egyptian Environmental Affairs Agency, (EEAA) Cairo, 1995.

[6]. AP. Dobson, Conservation and Biodiversity (Scientific American Library, NewYork 2000) 264p.

[7]. A F. Authman, Phenolics, terpenoids and bioactivity of sideritia taurica family lamiaceae. M.Sc.thesis., Faculty of Pharm., Cairo University (Egy.), Center Library, 2001.

[8]. KA. Abdel-Shafiq, Chemical studies on certain plants of family Labiate, M.Sc. thesis., Chemistry Dep. Faculty of Science, Cairo University. PP.174,1997.

[9]. S. Sajjadi, Analysis of essential oil of Nepeta sintenisii Bornm from Iran. Journal of Faculty of Pharmacy-Teheran- University-ofMedical-Sciences, 13 (2), 2005, 61-64.

[10]. V. Tachholm, Student`s Flora of Egypt (Cairo University, 2 nd Edition Coop.Beirut,1974).

[11]. JS. Kim, Compositions for inducing secretion of insulin-like growth factor-1. US6984405, 2006.

[12]. IL. Ben Amor, J. Boubaker, M. Ben Sgaier, I. Skandrani, W. Bhouri, A. Neffati, S. Kilani, I. Bouhlel, K. Ghedira, L. ChekirGhedira, Phytochemistry and biological activities of Phlomis species. Journal of Ethnopharmacology 125 ,2009, 183-202

[13]. A. Zargari, Medicinal Plants (Tehran University Publications,Tehran, Iran, 4th edition). 
Molecular analysis of some endemic and near-endemic medicinal plants located at Saint Katherine,

[14]. KD. Bauer, H. Garbe, and H. Surburg, Common Fragrance and Flavor (Materials, Wiley-VCH,Weinheim, Germany, 1997).

[15]. JG. Williams, Kubelik A R, Livak K J and Rafalski J A, DNA polymorphisms amplified by arbitrary primers are useful as genetic markers. Nucleic Acids Res. 18(22), 1990, 6531-6535.

[16]. R. Witkus, J. Deobley, and F. Wendel, Nuclear DNA markers in systemitics and evolution. In: Philips R.L; and Vasil J.K (eds). DNA Based Markers in Plants. (Kluwer Academic Publ., Dordrecht, The Netherlands, 1994) pp 116-141.

[17]. MA. Elkholy, M. Mansour1 and K. Omar, Genetic variability of Nepeta septemcrenata Benth. (Lamiaceae) Assessed by RAPD Markers. New York Science Journal;4(6), 2011, 97-105.

[18]. G. Agostini, TT. de Souza-Chies and S. Echeverrigaray, Genetic Diversity of Cunila Incisa Benth. (Lamiaceae). Medicinal \& Aromatic Plants, 1(4), 2012, 1-3

[19]. ZS. Javan, F. Rahmani, R.Heidar, Assessment of genetic variation of genus Salvia by RAPD and ISSR markers. AJCS 6(6), 2012,1068-1073

[20]. AR. Rustaiee, A. Yavari, V. Nazeri, M. Shokrpour, F. Sefidkon and M. Rasouli, Genetic diversity and chemical polymorphism of some Thymus species. Chem Biodivers 10(6), 2013, 1088-1098.

[21]. E. Solyman and R. Alkowni, RAPD for Assessment of Thymes Genetic Diversity in Palestine. Palestine Technical University Research Journal, 2(2), 2014, 01-08.

[22]. E. Zietkiewicz, A. Rafalski, D. Labuda , Genome fingerprinting by simple sequence repeat (SSR)- anchored polymerase chain reaction amplification. Genomics 20(2), 1994, 176-183

[23]. M. Pharmawati, G. Yan, IJ. McFarlane, Application of RAPD and ISSR markers to analyse molecular relationships in Grevillea (Proteaceae). Aust Syst Bot 17(1), 2004, 49-61.

[24]. M. Smolik, D. Jadczak2, A. Główczyk, Assessment of morphological and genetic variability in chosen Nepeta Accessions. Herba Polonica, 54 (4), 2008, 68-78.

[25]. M. Smolik, D. Jadczak, S. Korzeniewska, Assessment of Morphological and Genetic Variability in some Thymus Accessions Using Molecular Markers. Not. Bot. Hort. Agrobot. Cluj 37 (2), 2009, 234-240.

[26]. IA. Schanzer, MV. Semenova, OV. Shelepova \& TV. VoronkovaS, Genetic diversity and natural hybridization in populations of clonal plants of Mentha aquatica L. (Lamiaceae) Wulfenia $19,2012,131-139$

[27]. M. Kameli, SM. Hesamzadeh Hejazi and M.Ebadi , Assessment of genetic diversity on populations of three satureja species in Iran using ISSR markers. Annals of Biological Research 4 (3), 2013, 64-72

[28]. M. Yousefiazarkhanian, A. Asghari, J. Ahmadi, B. Asghari and AA. Jafari, Genetic Diversity Assessment of some Salvia sp. Ecotypes Based on ISSR Markers. Biological Forum - An International Journal 7(1),2015, 286-288

[29]. F. Koohdar, M. Sheidai, F. Attar and T. Seyed-Mehdi, Population genetic structure and genetic diversity in Dracocephalum thymiflorumL. (Lamiaceae) populations in Iran. Molecular Plant Breeding,6(19), 2015, 1-7.

[30]. V. Yousefi , A. Najaphy, A. Zebarjadi and H. Safari, Molecular characterization of Thymus species using ISSR Markers.The Journal of Animal \& Plant Sciences 25(4),2015, 1087-1094.

[31]. OH.Evren, E.Y“uzbasioglu \& MY.Dadand, Determination of intra-specific genetic variation of Phlomis kurdica and Phlomis oppositiflora and investigation for the hybridity of P. x melitenense (Lamiaceae) by means of molecular markers. Institute of Botany, Slovak Academy of SciencUesn. 70(9), 2015, 1159-1171.

[32]. HK. Patel, R S. Fougat, S.Kumar, JG. Mistry and M. Kumar, Detection of genetic variation in Ocimum species using RAPD and ISSR markers. 3 Biotech. 5(5), 2016, 697-707

[33]. S. Saha, S. Adhikari, T. Dey, P. Ghosh, RAPD and ISSR based evaluation of genetic stability of micropropagated plantlets of Morus alba L. variety S-1. Meta Gene 7, 2016, 7-15.

[34]. J. Welsh, and M. McClelland, Fingerprinting genomes using PCR with arbitrary primers. Nucleic Acids Res. 18(24), 1990, 72137218.

[35]. AD. Wolfe, QY. Xiang and SR. Kephort, Assessing hybridization in natural populations of penstemon (Scrophulariaceae) using hypervariable inter simple sequence repeat markers. Mol. Ecol 7(9), 1998, 1107-1125.

[36]. A. Junghans and M. Metzlatt, A simple and rapid method for the preparation of total plant DNA, Biotechniques ,8 (2), 1990,176

[37]. BCY.Collard,and DJ. Mackill, Start codon targeted (SCoT) polymorphism: a simple, novel DNA marker technique for generating gene targeted markers in plants. Plant Mol. Biol. Rep. 27, 2009, 86-93.

[38]. M. Nei, Estimation of average heterozygosity and genetic distance from a small number of individuals. Genetics 89(3), 1978, 583590 .

[39]. PR. Hunter, Reproducibility and indices of discriminatory power of microbial typing methods. Journal of Clinical Microbiology 28 (9), 1990, 1903-1905.

[40]. C. Tessier, J. David , P. This, JM. Boursiquot and A. Charrier Optimization of the choice of molecular markers for varietals identification in Vitis vinifeara L. Theor. Appl. Genet 98, 1999, 171-177

[41]. P. Sharma, V. Sharma and V. Kumar (2014). Genetic diversity analysis of cluster bean Cyanomopsis tetragonoloba (L.) Taub genotypes using RAPD and ISSR markers. J. Agr. Sci. Tech., 16, 2014, 433-443. 